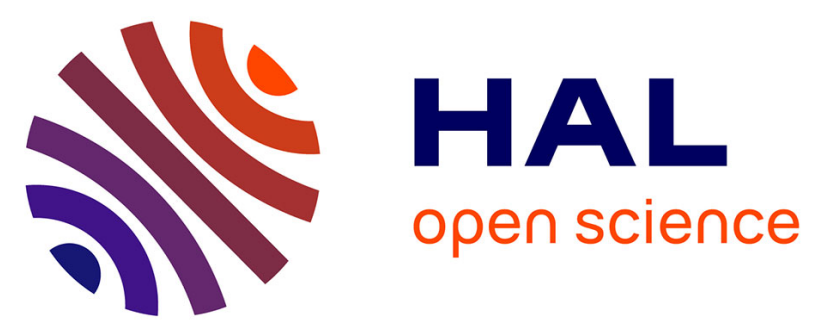

\title{
Free fatty acids in Lake Aydat catchment soils (French Massif Central): sources, distributions and potential use as sediment biomarkers
}

Renata Zocatelli, Marlène Lavrieux, Jean-Robert Disnar, Claude Le Milbeau, Jérémy Jacob, Jean-Gabriel Bréhéret

\section{To cite this version:}

Renata Zocatelli, Marlène Lavrieux, Jean-Robert Disnar, Claude Le Milbeau, Jérémy Jacob, et al.. Free fatty acids in Lake Aydat catchment soils (French Massif Central): sources, distributions and potential use as sediment biomarkers. Journal of Soils and Sediments, 2012, 12, pp.734-748. 10.1007/s11368-012-0505-1 . insu-00681805

\section{HAL Id: insu-00681805 https://hal-insu.archives-ouvertes.fr/insu-00681805}

Submitted on 22 Mar 2012

HAL is a multi-disciplinary open access archive for the deposit and dissemination of scientific research documents, whether they are published or not. The documents may come from teaching and research institutions in France or abroad, or from public or private research centers.
L'archive ouverte pluridisciplinaire HAL, est destinée au dépôt et à la diffusion de documents scientifiques de niveau recherche, publiés ou non, émanant des établissements d'enseignement et de recherche français ou étrangers, des laboratoires publics ou privés. 
SOILS, SEC \# • RESEARCH ARTICLE

Free fatty acids in Lake Aydat catchment soils (French Massif Central): sources, distributions and potential use as sediment biomarkers

Renata Zocatelli • Marlène Lavrieux • Jean-Robert Disnar • Claude Le Milbeau • Jérémy Jacob • Jean Gabriel Bréheret

R. Zocatelli $(\bowtie) \bullet$ M. Lavrieux • J.-R. Disnar • C. Le Milbeau • J. Jacob

Université d'Orléans, ISTO, UMR 7327, 45071, Orléans, France

CNRS/INSU, ISTO, UMR 7327, 45071 Orléans, France

BRGM, ISTO, UMR 7327, BP 36009, 45060 Orléans, France

e-mail: renata.zocatelli@cnrs-orleans.fr

\title{
M. Lavrieux • J. G. Bréheret
}

Université François-Rabelais de Tours, Département Géosciences - Environnement, Laboratoire de Géologie Parc Grandmont F-37200, Tours, France

\section{$(\bowtie)$ Corresponding author:}

\section{Renata Zocatelli}

e-mail: renata.zocatelli@cnrs-orleans.fr

\begin{abstract}
Purpose: Eighteen soils were sampled in the Lake Aydat catchment in order to analyse free fatty acid (FA) content; FAs are considered to be among the most amenable biomarkers to mobilisation by runoff waters. The majority of the study area has soil cover consisting of grasslands or forest since the 2nd World War, although some covers having changed more recently.

Material and methods: The soil studied all developed on volcanic rocks (andisols). The bulk organic matter (OM) content of the samples was characterized by Rock-Eval (RE) pyrolysis. The FAs were determined by gas chromatography-mass spectrometry (GC-MS) analysis of isolated and derivatized (methylation and trimethylsilylation) FA fractions.

Results and discussion: Few low molecular weight compounds (LMW; i.e., $\left\langle\mathrm{C}_{20}\right.$ ) were detected; FA distributions were dominated by even numbered-carbon high molecular weight (HMW; $\geq \mathrm{C}_{20}$ ) normal FAs and difunctionalized FAs that included: dicarboxylic acids (diFAs), n-alkylcarboxylic acids (nFAs), and $\alpha$ - and $\omega$ hydroxycarboxylic acids ( $\alpha$ HOFAs and $\omega$ HOFAs). The distributions and abundances of HMW terms of all families (which can be all considered as representative of terrestrial OM source) displayed only slight differences. These differences were rationalized by the following ratios: $\left(\mathrm{C}_{26: 0}+\mathrm{C}_{28: 0}\right) / \Sigma \mathrm{C}_{\text {even }} \mathrm{nFAs}, \mathrm{C}_{22} / \mathrm{C}_{24}$ di-FAs, and $\mathrm{C}_{20}$ $/ \mathrm{C}_{20+}(\omega$-HOFAs). Soils from areas that had changed use recently consistently displayed intermediate ratio values
\end{abstract}


typical of their double inheritance. All grassland soils and some samples from intermediate areas contained notable amounts of the bile acid deoxycholic acid that testifies to their present or recent use for cattle breeding. Conclusions: Despite the variety and the abundance of all HMW FAs in soils, work done previously on Lake Aydat sediments found only nFAs (Stefanova, M. and Disnar, J. R. 2000. Composition and early diagenesis of FAs in lacustrine sediments, Lake Aydat (France). Org Geochem 31, 41-55). These results suggest we should question the importance of the watershed contribution, the source (plant or soil) and mode of transportation of the FAs to the lake sediments.

Keywords: Biomarkers $\bullet$ Conifer $\bullet$ Fatty acids $\bullet$ French Massif Central $\bullet$ Grassland $\bullet$ Sediments $\bullet$ Soils

\section{Introduction}

Fatty acids (FAs) are major components of the lipids of living organisms. They mostly occur: (i) in the form of esters (of alkanols, sterols and glycerol) if they are components of the cell membranes of bacteria and eukaryotes; (iia) as polyesters in the protective tissues of higher plants (namely cutin in leaves and suberin in barks and roots); and also (iib) in the free or combined state (waxes) at the outer surface of leaves (Feng et al. 2010 and references therein). Similar to other lipid compounds, FAs have been extensively studied by organic geochemists as tracers of plant input to marine and lacustrine sediments (Cranwell 1977, 1978, 1981; Meyers and Ishiwatari 1993; Ho and Meyers 1994; Prartono and Wolff 1998; Ficken et al. 2000; Fisher et al. 2003; Jacob et al. 2007). While the FAs incorporated into phospholipids have received considerable attention as specific tracers of soil microorganisms (Zelles 1997, 1999; Ruess and Chamberlain 2010 and references therein), soil lipids, including FAs, have been little investigated. This paucity of data was pointed out by Bull et al. (2000a), and still remains fully valid, despite the publication of a few papers in the meantime (see below). Most papers on soil lipids in general and FAs in particular deal with the fate or turnover of lipid components of the soil organic matter (SOM) in cultivated or uncultivated soils (Dinel et al. 1998; Nierop and Verstraten 2005; Otto and Simpson 2006; Wiesenberg and Schwark 2006; Wiesenberg et al. 2008, 2010; Amelung et al. 2008; Feng et al. 2010 and references therein). Only very few papers consider FAs as plant source indicators (Almendros et al. 1996; van Bergen et al. 1997; Bull et al. 2000b; Gleixner et al. 2001; Marseille et al. 1999). Both these objectives are considered together in studies in which lipids are used for tracking changes in soil use (Lichtfouse et al. 1994; Wiesenberg et al. 2004; Quénea et al. 2006).

As soil scientists, sediment geochemists usually base the identification of the source organisms of FAs (and other lipid compounds) on the composition of the putative living organism (e.g., Cranwell 1974; Rieley et al. 1991). The possibility that original FA distributions might be altered during compound transfer from plant source to downstream sediment trap (lake or sea) - and especially in the soil where they can remain for a rather long time - is generally overlooked (e.g., Kusch et al. 2010).

A few years ago, Stefanova and Disnar (2000) published a study on the free and bound FA content in the recent sediments of Lake Aydat (> ca. 1950). This lake is located in the French Massif Central, in an area covered by grasslands and forests. It is presently eutrophic and, accordingly, the previous authors evidenced only a minor organic contribution from the watershed to the lake sediment as per the results of their FA study. The present study deals with the analysis of the free FAs extracted from 18 representative soils in relation to the different 
vegetation cover and topographic conditions (orientation and slope) in the lake catchment. This work has a threefold interest: 1) to evaluate the variations in the content and natural composition of free FAs, 2) to check their ability to differentiate the vegetation covers as a source of FAs and 3) their possible use as biomarkers from catchment. To answer these questions we selected soils under different plant cover (i.e., grass and trees) and over a range of environmental factors (soil characteristics, elevation, slope, etc.). Some of the studied soils that have experienced changes in land use during the last century should also allow us to assess the persistence of FAs from historic land uses and, accordingly, to test the potential of lipids to track such changes.

\section{Setting}

Soil samples were taken from the catchment of Lake Aydat, located in the French Massif Central, about $25 \mathrm{~km}$ $\mathrm{SW}$ of Clermont-Ferrand (Fig. 1). The catchment is at an altitude ranging from $825 \mathrm{~m}$ (lake level) to about 1300 $\mathrm{m}$ above sea level. The highest points are volcanoes of the Chaîne des Puys. Between the volcanic domes flows the Veyre River, the major tributary of Lake Aydat. The Lake Aydat catchment comprises rather shallow soils developed on recent volcanic rocks (i.e. younger than 70000 years, one of the latest manifestations of the volcanic activity being the basaltic flow that dammed the Veyre river valley about 8600 years ago, giving birth to Lake Aydat). The area was most certainly covered by forest until its intensive exploitation for the development of agriculture, from the middle of the first millennium (Michelin 1996). Nowadays, in the Aydat catchment, the areas of greatest slope are no longer used as pasture and are covered by forest or by shrubby meadows (Table 1 and Fig. 1). Here, the areas designated as "intermediate" were used as grasslands until the end of the 1940's and are presently abandoned (namely S05, S28, S33 and S34; Institut Géographique National, 1946).

The volcanoes are presently covered by forests (mainly Picea sp.), most of them being recent plantations, whereas the rest of the catchment is covered by pastures (grasslands) and, in lesser abundance, by shrubs. In total, the present watershed comprises $70 \%$ grasslands, $15 \%$ forest, with the rest being urbanized areas. The geological substratum is mostly basaltic, accompanied by basaltic trachyandesite and Quaternary alluvium near the Veyre River. Aydat soils are andisols, constituted by lightly-textured basic lava. Sand-silt constituted the only horizon (A, organo-mineral) above the $\mathrm{C}$ horizon. These soils are well drained and slightly acidic. The abundance of worm casts and molehills indicates a high degree of biological activity.

\section{Materials and methods}

\subsection{Sampling, soil characterization and slope calculation}

Eighteen soil monoliths, representative of the diversity of soil present in the catchment of Lake Aydat, were sampled in autumn 2008. The location and context of the eighteen sites are described in Fig. 1 and the vegetation cover and the main characteristics of the selected soils are listed in Table 1. Slope calculations were performed according to Kasel and Bennett (2007). Samples of the top of superficial organo-mineral horizon $(2-4 \mathrm{~cm})$ were dried in an oven $\left(40^{\circ} \mathrm{C}\right)$, crushed and sieved at $2 \mathrm{~mm}$. The $<2 \mathrm{~mm}$ fractions were analysed.

\subsection{1. $\mathrm{pH}$ and granulometry}

Soil $\mathrm{pH}$ was determined as described in Margesin and Schinner (2005). Granulometry was performed on airdried samples on the $<2 \mathrm{~mm}$ fraction from one sample within each of the three land uses. The size distribution of particles was determined using the pipette method after dispersion with 1M NaOH (Embrapa 1997). 


\subsubsection{Rock-Eval analyses}

Approximately $60 \mathrm{mg}$ of dried and crushed soils were used for RE analysis. The RE parameters used in this study were: (i) Total Organic Carbon (TOC; \%) that accounts for the quantity of OC present in the soil; (ii) the Hydrogen Index (HI, in mg hydrocarbons. ${ }^{-1}$ TOC), which is the amount of HC released during pyrolysis, normalized to TOC and (iii) the Oxygen Index (OI, in $\mathrm{mg} \mathrm{CO}_{2} \cdot \mathrm{g}^{-1} \mathrm{TOC}$ ) that corresponds to the oxygen content of the OM released during pyrolysis, normalized to TOC (Espitalié et al. 1985; Lafargue et al. 1998; Disnar et al. 2003).

\subsection{Lipid extraction and analysis by Gas Chromatography-Mass Spectrometry (GC-MS)}

Lipids were extracted from ca. $2 \mathrm{~g}$ of dried and crushed soil samples using accelerated solvent extraction with $\mathrm{CH}_{2} \mathrm{Cl}_{2}: \mathrm{MeOH}\left(1: 1 \mathrm{v} / \mathrm{v}\right.$; ASE 200 Dionex $\left.{ }^{\circledR}\right)$ at $100^{\circ} \mathrm{C}$ and 1000 psi for $5 \mathrm{~min}$ in 3 cycles $(5 \mathrm{ml}$ cells, $60 \%$ flush volume). The total extract was dried under $\mathrm{N}_{2}$ and then fractionated into neutral and acidic compounds using solid phase extraction on Aminopropyl Bond Elute $\bigcirc$ phase according to Jacob et al. (2005). Acid fractions were dried under $\mathrm{N}_{2}$ and methylated by adding a mixture of anhydrous $\mathrm{MeOH}$ and acetyl chloride kept at room temperature for 1 hour. The obtained methyl esters were then further derivatized by reacting with $125 \mu$ N,Obis(trimethylsilyl)trifluoroacetamide (BSTFA) in $250 \mu$ l pyridine at $60^{\circ} \mathrm{C}$ during 1 hour. Standard (5 $\alpha$-cholestane) was added prior to GC-MS analysis.

Esterified and silylated acid fractions were analyzed by GC-MS with a Polaris TRACE-GCQ. The chromatograph was fitted with an Rtx-5MS column $(30 \mathrm{~m}, 0.25 \mathrm{~mm}$ i.d., $0.25 \mu \mathrm{m}$ film thickness). The GC operating conditions were: $40^{\circ} \mathrm{C}$ (hold $1 \mathrm{~min}$ ) ramping from $40^{\circ} \mathrm{C}$ to $120^{\circ} \mathrm{C}$ at $30^{\circ} \mathrm{C} \cdot \mathrm{min}^{-1}$, then from $120^{\circ} \mathrm{C}$ to $300^{\circ} \mathrm{C}$ at $5^{\circ} \mathrm{C} \cdot \mathrm{min}^{-1}$, hold $30 \mathrm{~min}$. The samples $(2.0 \mu \mathrm{l})$ were injected automatically in splitless mode, with the injector temperature set at $280^{\circ} \mathrm{C}$. Helium was the carrier gas $\left(1 \mathrm{ml} \cdot \mathrm{min}^{-1}\right)$. The mass spectrometer was operated in the electron ionization (EI) mode at $70 \mathrm{eV}$ and scanned from 50 to $650 \mathrm{~m} / \mathrm{z}$. Identifications were based on GC retention times and comparison of mass spectra with published data. Because of possible coelution, the concentrations were estimated by measuring peak areas on ion specific chromatograms. Acid concentrations were estimated after calculating a correction factor between the peak area on the ion specific chromatogram and the peak area on the Total Ion Current (TIC) and then reported to the area of standard peak ( $5 \alpha$-cholestane) on the TIC. The Pearson product moment correlation was used to test for correlation with Statistica (Statsoft 2008). The level of significance of all tests was set at $\mathrm{P}<0.05$.

\section{Results}

The samples analysed were separated into three groups depending on their present and past vegetation cover: forests, grasslands and intermediate areas that have changed occupation during the past century. In most cases these intermediate areas correspond to abandoned grasslands that were colonized by shrubs and/or trees (mostly conifers).

\subsection{Soil samples main characteristics (Table 1)}

All the samples are rich in TOC, with the range being between $5.2 \%$, the value obtained for grassland soil S14, up to $38.2 \%$ in the forest sample S26 (Table 1). Grassland soils in general exhibited lower TOC values (average 
$=10.8 \%, \mathrm{SD}=5.6 \%$ ) than both intermediate site soils (average $=16.1 \%, \mathrm{sd}=6.9 \%$ ) and forest soils, except for site S12 (25.7\%) that was located in a swampy area. Slope values were low to moderate, ranging from 0.5 to $16.6^{\circ}$. The largest slope gradients were reached in forest soils (average $=15.8^{\circ}$ ) whereas grasslands developed on lower slopes (average $=6.9^{\circ}, \mathrm{SD}=4.5$ ). OI values were relatively higher in forest soil samples (e.g. sample S26, has the high OI value but also the highest HI, the greatest slope and the lowest pH value: 4.2). Granulometry revealed a gradient from grassland to forest soils, characterized by a decreasing amount of silts compensated by an increase in sand, accompanied by a slight decrease in $\mathrm{pH}$ (Table 1).

\subsection{Identification, composition and distribution of lipids in the acid fraction of soil samples}

The free FA fraction of the soil total lipid extract (TLE) contained the following groups of aliphatic compounds: nFAs, diFAs, $\omega$ - and $\alpha$-HOFAs. Total fatty acids (TFA) concentrations varied between 823 and $6794 \mu \mathrm{g} / \mathrm{g}$ TOC for grassland soils, between 1639 and $6636 \mu \mathrm{g} / \mathrm{g}$ TOC for intermediate soils, and between 833 and $23346 \mu \mathrm{g} / \mathrm{g}$ TOC in forest soils (Table 1). Characteristic chromatograms of the acid extractable fractions from grassland and forest soils are shown in Fig. 2.

\subsection{1 n-alkylcarboxylic acids (nFAs)}

The total abundance of nFAs ranged from 396 to $6318 \mu \mathrm{g} / \mathrm{g}$ TOC/sample, making it the most abundant family of free FAs in grassland and intermediate soils (53 to $68 \%$ of TFA). Fig. 3 summarizes the distributions of nFAs from each group of vegetation cover studied. In all cases, $n F A s$ ranged from $n-\mathrm{C}_{16: 0}$ to $n$ - $\mathrm{C}_{34: 0}$ and displayed an even-over-odd predominance. In grassland samples (Fig. 3a; 3b), nFAs showed a monomodal distribution, with a maximum at $n-\mathrm{C}_{26: 0}$. In forest soils and sample $\mathrm{S} 34$ (intermediate vegetation; Fig. $3 \mathrm{~d}$ ), nFAs showed similar concentrations of $n-\mathrm{C}_{22: 0}, n-\mathrm{C}_{24: 0}, n-\mathrm{C}_{26: 0}$ and $n-\mathrm{C}_{28: 0}$ (Fig. 3e; 3f).

\subsection{2 $\omega$-hydroxycarboxylic acids ( $\omega$ HOFAs)}

$\omega$ HOFAs represented between 34 to $65 \%$ of the TFA for forest soils. In grassland and intermediate soils this compound family was less abundant than the nFAs and represented up to $28 \%$ of the TFA. All samples presented a homologous series of compounds ranging from $\mathrm{C}_{12}-\omega \mathrm{HOFA}$ to $\mathrm{C}_{29}-\omega \mathrm{HOFA}$ with an even-over-odd predominance. The distribution was monomodal in grassland soils and bimodal in intermediate and forest soils. High abundances of the $\mathrm{C}_{22}-\omega \mathrm{HOFA}$ and $\mathrm{C}_{24}-\omega \mathrm{HOFA}$ homologues were recorded in grassland and intermediate soils (Fig. 4a; $4 \mathrm{~d}$ ), with higher concentrations than the $n-\mathrm{C}_{22: 0}$ and $n-\mathrm{C}_{24: 0} n F A s$, respectively. Forest soil samples (Fig. 4e; 4f) exhibited an exceptionally high abundance of $\mathrm{C}_{12}, \mathrm{C}_{14}$ and $\mathrm{C}_{16}-\omega \mathrm{HOFA}$. Intermediate soil sample S34 (Fig. 4d) showed the characteristics of grassland and forest soils, the major compounds being $\mathrm{C}_{22}, \mathrm{C}_{24}$ and $\mathrm{C}_{16}-\omega \mathrm{HOFA}$, respectively.

\subsection{3 $\alpha$-Hydroxycarboxylic acids ( $\alpha H O F A s$ )}

$\alpha$-Hydroxycarboxylic acids ( $\alpha \mathrm{HOFA}$ ) represented between 8 and $22 \%$ of aliphatic acids in grassland soil TFAs, between 11 and $23 \%$ in intermediate soils and between 5 and $12 \%$ in forest soils. Homologous series ranged from $\mathrm{C}_{20}$ to $\mathrm{C}_{30}$. In all samples, $\mathrm{C}_{24}-\alpha \mathrm{HOFA}$ was the dominant homologue, followed by notable and comparable levels of all homologues from $\mathrm{C}_{22}$ to $\mathrm{C}_{26}$, including odd-numbered chains (Fig. 5). 


\subsubsection{Dicarboxylic acids (diFAs)}

All samples displayed a homologous series of diFAs extending from $\mathrm{C}_{20}$ to $\mathrm{C}_{26}$ with a marked even-over-odd predominance. DiFA distributions showed a maximum at $\mathrm{C}_{24}$, with high $\mathrm{C}_{22}$-diFA proportions in grassland and intermediate soils (Fig. 6a; 6d). In forest soil samples, diFA distributions were dominated by $\mathrm{C}_{22}$-diFA, followed by $\mathrm{C}_{24}$ and $\mathrm{C}_{20}$-diFAs (Fig. 6e,f).

\subsubsection{Other compounds}

In the Aydat catchment area, traces of $\mathrm{nC}_{22}, \mathrm{nC}_{24}$ and $\mathrm{nC}_{26}$ alkanols were observed in some soil samples regardless of the vegetation cover. These compounds represented a simple and modest contamination of the FA fraction by dominant compounds of the neutral lipid fraction (ca. 0.04\% of the TFA). Deoxycholic acid, a bile acid, was found at notable levels in all grassland soils but one (from a shrubby area), and in most of those from intermediate areas (Fig. 8).

\section{Discussion}

5.1 Abundance and preservation of SOM and FAs in catchment soils With TOC contents between 5\% and $38.2 \%$, all the studied samples were rich in OM irrespective of their vegetation cover (grassland S12: $25.7 \%$; forest S26: $38.2 \%$; intermediate S33: 29.7\% TOC; Table 1). This richness provides preliminary evidence for a rather long residence time of SOM and consequently for good OM preservation. More direct indications were provided by RE parameters (HI and OI values). For example, samples $\mathrm{S} 26$ and S33, which were among the richest in OM, also presented relatively high $\mathrm{HI}$ and low OI values (namely in the $360-380 \mathrm{mgHC} \cdot \mathrm{g}^{-1} \mathrm{TOC}$ and $170-250 \mathrm{mgCO}_{2} \cdot \mathrm{g}^{-1} \mathrm{TOC}$ ranges; Table 1). Such HI and OI values that are common for forest litter in temperate areas are also typical for well-preserved type III OM (Disnar et al. 2003). In contrast, sample S36, which also originated from a forest soil and which contained only $8 \%$ TOC, presented lower $\mathrm{HI}$ and higher OI values (i.e. $220 \mathrm{mgHC} . \mathrm{g}^{-1} \mathrm{TOC}$ and $378 \mathrm{mgCO}_{2} \cdot \mathrm{g}^{-1} \mathrm{TOC}$, respectively; Table 1) that constituted a clear indication of a more intensive OM alteration than the other samples. Despite this alteration, sample S36 had an extremely high FA content that suggests a better preservation of these compounds than bulk SOM, in agreement with general knowledge on the greater resistance of lipids compared to other biochemical compounds to (bio-)degradation (namely proteins and polysaccharides; Tissot and Welte 1984).

At the molecular scale, the overall good FA preservation is first evidenced by high even-over-odd compound predominance in the four compound families examined (Zelles 1997; Jandl et al. 2005; Disnar et al. 2005). The low contents of odd $\mathrm{C}$ numbered FAs strongly suggests that there has been no significant contribution from products of the oxidative degradation of alkanols or $n$-alkanes, via methyl ketones (Amblès et al. 1994; Bull et al. 2000b). From a general point of view, soil lipids can indeed be affected by chemical processes such as hydrolysis and transesterification of lipid esters and further by oxidation and reduction. The latter processes are dependent on soil $\mathrm{pH}$ and moisture, but also on other environmental factors such as the clay content, the nature of the microbial biomass, and the vegetation types (van Bergen et al. 1997). In the present case, two of these factors might immediately be suspected of having played a notable role in the preservation of FAs, and more generally of SOM. The first one is acidity since, as has long been observed, the preservation of soil lipids is primarily favored by a low pH (Moucawi et al. 1981; Jambu et al. 1985, 1987; van Bergen et al. 1998), although acidity favours the hydrolysis of biopolymers (Nierop et al. 2005) and the selective preservation of certain types of FAs, 
especially aliphatic compounds (Bull et al. 2000a; Nierop and Verstraten 2003). The second factor is the volcanic nature of the soil parent material that might have given rise to abundant non-crystalline minerals. These are thought to be capable of forming stable organo-mineral complexes that might favour physical protection of SOM (Torn et al. 1997). In fact, this hypothesis has been contradicted by recent work (Buurman et al. 2007) and thus remains to be confirmed. Nevertheless, the role played by minerals in OM preservation is a generally accepted concept (e.g., Six et al. 2002).

\subsection{Acid compounds as potential biomarkers in catchment soils}

First, it is worth noting the low proportion of LMW nFAs $\mathrm{C}_{16: 0}$ and $\mathrm{C}_{18: 0}$, and above all the absence of their unsaturated counterparts such as $n$ - $\mathrm{C}_{18: 1}$ and/or $n$ - $\mathrm{C}_{18: 2}$ (i.e., linoleic acid). The latter compounds are frequently detected at variable concentrations in plant lipids, for example in the TLE as well as in the hydrolysate of the residue of the grass Holcus latanus (Bull et al. 2000b). In contrast, both these compounds and especially $n$ - $\mathrm{C}_{18: 2}$ were only present at low levels in the soil where this grass grew. This is consistent with the high biodegradability of the LMW saturated and unsaturated FAs (Marseille et al. 1999).

With the exception of the LMW $\omega$ HOFAs that are particularly abundant in soil sample S36 (cf. section 5.1; Fig. 4), all Aydat catchment soils display similar or at least comparable FA distributions, whatever their plant cover or the compound family considered (Figs 3-6).

Among all the compound families examined, nFAs display the widest distribution of homologues, at least from $n$ - $\mathrm{C}_{16: 0}$ to $n$ - $\mathrm{C}_{34: 0}$ (Fig. 3). This family of compounds is usually divided into LMW and HMW compounds [i.e. $n$ $\mathrm{C}_{20 \text { - }}$ and $n-\mathrm{C}_{20+}$ (including $\left.n-\mathrm{C}_{20}\right)$ ], which is consistent with the reputed origin of these two sub-groups: the cellular membrane for the former and epicuticular waxes for the latter (Kolattukudy 1980). In contrast to the former that are ubiquitous and rather easily biodegraded as a result of their biological location and of their rather low molecular weight (e.g., Marseille et al. 1999), the latter are quite resistant and are thus frequently used as plant source indicators in sediment studies. However, in such cases they are generally considered as "markers of higher plants" without any further detail (Tissot and Welte 1984; Baudin et al. 2010), disregarding the fact that compound distributions are also known to vary depending on the species studied (e.g., Rieley et al. 1991), but also on the age of the plant (Martins et al. 1999; Lecomte 2009), and many abiotic factors such as light, temperature, osmotic stress, etc (Shepherd and Griffiths 2006).

Among the various other FA families observed in the studied samples, $\omega$ HOFAs were frequently present at high concentration levels, i.e. almost identical to those of nFAs (Fig. 2). As is particularly well exemplified by the altered forest sample S36 (cf. previous section), this compound family presents a bimodal distribution similar to that of nFAs, with a first mode in the LMW range (i.e., at $\mathrm{C}_{16}$ ) and a second mode in the HMW range, at $\mathrm{C}_{22}$ (Fig. 4). Based on early studies (Eglinton and Hunneman 1968; Holloway 1982), authors usually assume that $\omega$ HOFA are cutin and/or suberin derivatives, irrespective of whether the wHOFAs were found in sediment samples (e.g., Huang et al. 1996; Wakeham 1999; Stefanova and Disnar 2000) or soils (van Bergen et al. 1998; Naafs et al. 2004; Bull et al. 2000b). In fact, the "long chain" [as designated by Eglinton and Hunneman (1968)] HOFAs constitutive of cutin are almost exclusively $\mathrm{C}_{16}$ and/or $\mathrm{C}_{18}$ mono, di and trihydroxy FAs (Espelie and Kolattukudy 1979; Holloway 1982; Goni and Hedges 1990; Järvinen 2010). Here, such LMW $\omega$ HOFA are present in all samples but especially in soils developed under forest. The absence of the $\mathrm{C}_{18}$ HOFA was also consistent with the distribution of $\omega$ HOFAs of two spruce species, including $P$. abies, the dominant tree species 
in the study area (Priigelt and Lognay 1996). This source assignment did not hold for the HMW $\omega \mathrm{HOFA}\left(\mathrm{C}_{20+}\right)$. However, in contrast to cutin, which comprises only LMW FAs $\left(\leq \mathrm{C}_{18}\right)$, suberin contains notable proportions of heavier terms. For example, Matzke and Riederer (1991) compared the chemical constitution of cutin and suberin from the leaves and the periderm (bark) of three major tree species (Picea abies L., Quercus robur L. and Fagus sylvatica $L$.), and found that the suberin-rich periderm from stems and branches of the three species (plus roots of Picea) yielded notable proportions of $\geq \mathrm{C}_{20} \omega$ HOFAs (up to $n-\mathrm{C}_{24: 0}$ for Picea and to $n-\mathrm{C}_{26: 0}$ for Fagus and Quercus $)$. These results strongly suggest that the HMW $\omega$ HOFAs $\left(\mathrm{C}_{20+}\right)$ in Aydat soils probably originated from the suberin of twigs, branches and roots of trees and/or grasses.

Among the various families examined, diFAs present the smallest number of homologues (namely, evennumbered carbon chain diFA from $\mathrm{C}_{20}$ to $\mathrm{C}_{26}$; Fig. 6 and Fig. 7c). An even smaller distribution of diFAs (i.e., $\mathrm{C}_{22} \mathrm{diFA}+\mathrm{C}_{24} \mathrm{diFA}$ only) was found in the grass Holcus lanatus and the underlying soil by Bull et al. (2000b). Among the plant samples analysed by Bull et al. (2000b) the almost exclusive presence of diFAs in the hydrolysates of roots and lipid extract of aerial parts of grasses substantiate their contribution to plant constitutive polymers, and especially to the suberin of roots. In addition, the absence of such compounds in nonhydrolysed plant samples and their presence in the soil provides clear evidence that the original polymers only start to undergo degradation (i.e., hydrolysis) once they have been incorporated in soils. According to Amblès et al. (1994) diFAs may well be formed by oxidation of $\omega$ HOFAs. However, the similarity in chain length of the dominant components in both families would in this case cause little alteration in component distribution. Suberin was probably also the source for the aHOFAs (Matzke and Riederer 1991). In addition to the case of trees, which has been well documented (see refs here above), $\mathrm{C}_{16}$ to $\mathrm{C}_{24}-\alpha \mathrm{HOFAs}$ have also been found in the roots and leaves of the herbaceous angiosperm Arabidopsis thaliana (Franke et al. 2005). As schematized in Fig. 5 , all the samples, whether they were taken in grassland or forest, showed a similar distribution of aHOFAs with notable amounts of even-carbon-numbered components in the $\mathrm{C}_{22}-\mathrm{C}_{26}$ range, and a maximum at $\mathrm{C}_{24}$.

\subsection{Differentiating source materials in catchment soils}

The greatest differentiation between grassland and forest is provided by the $\omega$ HOFAs and especially by the abundance of the LMW terms (Fig. 7), even in the absence of extensive alteration such as that experienced by sample S36. In forest soils, the importance of the annual needle litterfall (notwithstanding the contribution of rather resistant suberin-rich branches and roots) could explain the dominance of LMW $\omega \mathrm{HOFA}$ (i.e. $\mathrm{C}_{12}$ to $\mathrm{C}_{16^{-}}$ $\omega \mathrm{HOFA}$; Fig. 4). In contrast, in grassland and intermediate area soils, the abundance of HMW $\omega \mathrm{HOFA}$ (i.e. $\mathrm{C}_{24^{-}}$ $\omega \mathrm{HOFA}$ and $\mathrm{C}_{22}-\omega \mathrm{HOFA}$; Fig. 7a) might underline a significant contribution of grass root suberin to SOM. In the latter case, most of the cutin-rich aerial plant production is either harvested (to make hay) or grazed by cattle. Although the residual matter can return to the soil after a transit through the cattle gut, either directly or due to manuring practices, the contribution of cutin from aerial parts of grasses to SOM might be minor when compared to suberin from roots. This distinction between cutin and suberin and their biomarkers is probably the most marked in an area such as that of Lake Aydat where forest litters that are prone to mobilisation by running waters are rich in leaves and/or needles (and consequently in cutin) whereas, in contrast, the suberin from plant roots of grasslands probably contributes predominantly to SOM formation, most of the cutin-rich aerial plant production being either grazed by the cattle or harvested (see here above).

The major differences between grasslands and forests have been tentatively rationalized by the following ratios: 
$\left(n-\mathrm{C}_{26: 0}+n-\mathrm{C}_{28: 0}\right) / \Sigma \mathrm{C}_{\text {even }} n \mathrm{nAs}, \mathrm{C}_{22} / \mathrm{C}_{24}$ di-FAs, and $\mathrm{C}_{20} / \mathrm{C}_{20+} \omega$-HOFAs (Fig. 7). For all of these ratios, a gradient between these two vegetation types emphasizes the characteristics of the intermediate area, sometimes close to grasslands, sometimes to forests. $n-\mathrm{C}_{26: 0}$, which constitutes the mode of nFA distributions in grassland soils, is also accompanied by $n-\mathrm{C}_{24: 0}$ in intermediate soils. In contrast, spruce forest soils do not display clear modal distributions, the even $\mathrm{C}$ numbered FAs homologues being all present at similar levels in the $n-\mathrm{C}_{22: 0}-n-\mathrm{C}_{28: 0}$ range. Accordingly, the $\left(n-\mathrm{C}_{26: 0}+n-\mathrm{C}_{28: 0}\right) / \Sigma \mathrm{n}_{\text {even }} \mathrm{nFA}$ ratio values decreased from an average of 0.65 in grassland soils (n $=12$; Fig. $7 \mathrm{~b})$ to 0.50 in intermediate soils $(\mathrm{n}=4)$ and down to 0.32 in forest soils $(\mathrm{n}=2)$. Grasslands and intermediate soils presented higher concentrations of $\mathrm{C}_{24} \mathrm{diFA}$ followed by $\mathrm{C}_{22} \mathrm{diFA}$, while forest soils had higher concentrations of $\mathrm{C}_{22}$ diFA followed by $\mathrm{C}_{20} \mathrm{diFA}$ and $\mathrm{C}_{24}$ diFA homologues. This allows us to propose the $\mathrm{C}_{22} / \mathrm{C}_{24}$ diFA ratio as a simple tool to differentiate grassland and intermediate soils from those of forest, in the Aydat catchment. The dominant $\omega$ HOFA homologues were $\mathrm{C}_{12}, \mathrm{C}_{14}$ and $\mathrm{C}_{16}$ in forest soils, and $\mathrm{C}_{24}$ and $\mathrm{C}_{22}$ in grassland soils (Fig. 7a). In intermediate area soils, the relatively high abundance of $\mathrm{C}_{16^{-}} \omega \mathrm{HOFA}, \mathrm{C}_{22}-\omega \mathrm{HOFA}$ and $\mathrm{C}_{24^{-}}$ $\omega \mathrm{HOFA}$, expressed as the $\mathrm{C}_{20} / \mathrm{C}_{20+} \omega \mathrm{HOFA}$ ratio (Fig. $7 \mathrm{~d}$ ), denotes their mixed grassland/forest influence.

\subsection{FA signatures as biomarkers for identifying land use change}

Carbon accumulation in soils depends on many factors, both anthropogenic and environmental (Kasel and Bennett 2007 and references therein). The Aydat catchment has been used by humans for forest exploitation and agriculture since at least the fifth century (Michelin 1996). A large part of the area currently predominated by grasslands or even forests was extensively used for agriculture for a period after the 2nd World War. A general problem in evaluating the impacts of land-use change is that the landscape is not used at random but with a preferential selection of soil types or positions best adapted for particular uses (e.g. Powers and Veldkamp 2005). Changes in vegetation cover affect soil properties, with consequential modifications on the OM content and molecular composition, which have long term impacts on the plant cover, e.g. plant communities developed after the afforestation of abandoned lands differ from ancient forests depending on the related modification of the soil properties (Glatzel 1991; Compton and Boone 2000; Heim et al. 2010). This behaviour has been shown to control vegetation diversity in forests (Foster 1992; Hermy 1994; Koerner et al. 1997) even 300 years after afforestation, and it has even been suggested that this situation could persist indefinitely (Dupouey et al. 2002). Finally, even if the relevant factors (soil characteristics, elevation, slope) do not allow a very clear discrimination, plant-derived organic acids permit some distinction of soils based on their respective uses (Fig. 7 and Table 1). In contrast, deoxycholic acid, the major bile acid excreted in the faeces of bovines, clearly identifies grasslands used as pastures and/or for manure spreading at present and in the recent past in the Aydat catchment (Fig. 8). This compound was found in notably high levels in almost all grassland soils and intermediate areas except two of these, which were probably more or less abandoned, as denoted by a rather dense shrub cover (S10 and S33; Fig. 8). The persistence of relatively high levels of deoxycholic acid in areas that have been abandoned for five to six decades is fully consistent with the previous statement that this biomarker might even be preserved over thousands of years in soils and sediments (Bull et al. 2002, 2003).

In addition to land-use, the slope of the soil could also play an important role in the accumulation of carbon and acid compounds. However, at Aydat, no significant correlation could be deduced from the comparison of slopes (Fig. 1 and Table 1) with TOC values (all $\mathrm{P}>0.05, \mathrm{R}=0.26)$ or slopes with soil FA contents $(\mathrm{P}>0.05, \mathrm{R}=0.19)$. 
5.5 FAs as potential indicators of terrestrial input to the sedimentary record

Lake Aydat is eutrophic, with seasonally abundant algal production (diatoms and cyanobacteria). Consequently, the amount of OM produced in the lake water body is certainly much more abundant than that provided by the catchment, thus strongly diluting the latter. A previous study on Aydat lacustrine sediments investigated the major free and bound lipid compounds recently deposited (> 1950) in the center of the lake (Stefanova and Disnar 2000). Among the compounds discussed here, only HMW nFAs (i.e. $\mathrm{C}_{20+}$ ) were ascribed to higher plants of the watershed. FA distributions of all the other families examined were highly dominated by LMW terms (i.e., $\mathrm{C}_{20}$-). Beginning with the highly dominant $\mathrm{nFAs}$ in $n-\mathrm{C}_{16: 0}$ and $n$ - $\mathrm{C}_{18: 0}$, all these LMW compounds were attributed either to autochthonous lacustrine production or to microorganisms. In soil samples, only $n$ - $\mathrm{C}_{16: 0}$ was found and in much lower proportions than HMW nFAs. This is consistent with the previously mentioned high biodegradability of these light ends (Marseille et al. 1999). In the sediment, diFAs ranging between $C_{16}$ and $C_{22}$ and maximizing at $\mathrm{C}_{16}$ were interpreted as originating from diatoms. A microbial source was also considered for the LMW $\alpha$ HOFAs $\left(\mathrm{C}_{20}\right)$ that were found in notable proportions in the sediment albeit not in the free fraction but in bound form. This origin was also confirmed by the presence of iso and anteiso forms of these components. Without going into further detail, this brief comparison between FA soil and sediment markers clearly demonstrated that despite favorable factors such as high contents of SOM in a generally good state of preservation, a rather wet mountainous climate and relatively steep slopes, few terrestrial plant markers were transported by runoff waters and finally accumulated in the lake sediments.

\section{Conclusions}

As depicted by high TOC contents and relatively high and low HI and OI RE index values, respectively, Lake Aydat catchment soils that are presently covered by either grassland or forest (spruce dominant), are all rich in well preserved OM. The soils' free FA content is globally dominated by various HMW $\left(\mathrm{C}_{20+}\right)$ compounds: $\mathrm{nFAs}$, diFAs, $\alpha$ HOFas and $\omega$ HOFAs; however, none of these compound families are specific to grasses or trees and consequently can consistently all be used as indicators of terrestrial $\mathrm{OM}$ as a whole, without any further distinction (as most authors usually do). Nevertheless, the forest soils are particularly rich in LMW $\omega$ HOFAs probably inherited from the cutin of needles and/or leaves. The abundance of these compounds, which increases with OM alteration, also denotes their relative stability with regard to that of the bulk OM. As generally admitted, HMW nFAs are mostly derived from plant leaf and needle cuticular waxes, and all the other oxygenated HMW compounds ( $\alpha$ HOFAs and diFAs) very likely from the suberin of roots and/or twigs and branches. Differences in the abundance of these various compounds between grasslands and forests soils has allowed us to propose the following molecular ratios: $\left(\mathrm{C}_{26: 0}+\mathrm{C}_{28: 0}\right) / \Sigma \mathrm{C}_{\text {even }} \mathrm{nFAs}, \mathrm{C}_{22} / \mathrm{C}_{24}$ di-FAs, and $\mathrm{C}_{20} / \mathrm{C}_{20+} \omega$-HOFAs to discriminate between soil samples. Consistently, grassland soils contained notable amounts of the bile acid deoxycholic acid. The preservation of this compound in soils that have changed use (e.g., from grassland to forest) witnesses their past use as pastures much more clearly than plant-derived FAs. Despite the abundance of a variety of HMW FAs, saturated nFAs were the only ones that had been previously found in sediments taken at the center of the lake (Stefanova and Disnar 2000). The exclusive presence of these compounds strongly suggests that: (i) there is only a very small delivery of FAs from these catchment soils to the lake and consequently (ii) these nFAs were most probably introduced directly by leaves and/or needles brought to the lake by the wind or runoff waters. Results 
showed here question the importance of other processes that are generally overlooked, beginning with the mode of transportation of the FAs from the soils to the lake sediments.

Acknowledgments This work received financial support from the ERODE (EC2CO, Centre National de la Recherche Scientifique/Institut National des Sciences de l'Univers) and OTARIE (Région Centre) projects. M. L. also acknowledges the Région Centre for attribution of PhD grant. E. Rowley-Jolivet is greatly thanked for corrections to the English. The authors wish to thank two anonymous reviewers for their constructive comments.

\section{References}

Almendros G, Sanz J, Velasco F (1996) Signatures of lipid assemblages in soils under continental Mediterranean forests. Eur J of Soil Sci 47:183-196

Amblès A, Jambu P, Parlanti E, Joffre J, Riffe C (1994) Incorporation of natural monoacids from plant residues into a hydromorphic forest podzol. Eur J of Soil Sci 45:175-182

Amelung W, Brodowski S, Sandahge-Hofmann A, Bol R (2008) Combining biomarker with stable isotope analyses for assessing the transformation and turnover of soil organic matter. In: Sparks DL (ed) Advances in agronomy, vol 100. Academic Press, Burlington

Baudin F, Disnar J R, Martinez P, Dennielou B (2010) Distribution of the organic matter in the channel-levees systems of the Congo mud-rich deep-sea fan (West Africa). Implication for deep offshore petroleum source rocks and global carbon cycle. Mar and Pet Geol 27:995-1010

van Bergen PF, Bull ID, Poulton PR, Evershed, R P (1997) Organic geochemical studies of soils from the Rothamsted classical experiments: I total lipid extracts, solvent insoluble residues and humic acids from broadbalk wilderness. Org Geochem 26:117-135

van Bergen PF, Nott CJ, Bull ID, Poulton PR, Evershed RP (1998) Organic geochemical studies of soils from the Rothamsted classical experiments. IV. Preliminary results from a study of the effect of soil $\mathrm{pH}$ on organic matter decay. Org Geochem 29:1779-1795

Bull ID, van Bergen PF, Nott CJ, Poulton PR, Evershed RP (2000a) Organic geochemical studies of soils from the Rothamsted classical experiments. V. The fate of lipids in different long-term experiments. Org Geochem 31:389-408

Bull ID, Nott CJ, van Bergen PF, Poulton PR, Evershed RP (2000b). Organic geochemical studies of soils from the Rothamsted classical experiments. VI. The occurrence and source of organic acids in an experimental grassland soil. Soil Biol and Biochem 32:1367-1376

Bull ID, Betancourt PP, Evershed RP (2002) An organic geochemical investigation of the practice of manuring at a Minoan site on Pseira Island, Crete. Geoarchaeology 16:223-242

Bull ID, Elhmmali MM, Roberts DJ, Evershed RP (2003) Using steroidal biomarkers to track the abandonement of a Roman wastewater course at the Agora (Athens, Greece). Archaeometry 45:149-161

Buurman P, Schellekens J, Fritze H, Nierop KGJ (2007) Selective depletion of organic matter in mottled podzol horizons. Soil Biol Biochem 39:607-621

Compton JE, Boone RD (2000) Long-term impacts of agriculture on soil carbon pools and nitrogen dynamics in New England forests. Ecology 81:2314-2330 
Cranwell PA (1974) Monocarboxylic acids in lake sediments: indicators derived from terrestrial and aquatic biota of paleoenvironmental trophic levels. Chem Geology 14:1-14

Cranwell PA (1977) Organic geochemistry of Cam Loch (Sutherland) sediments. Chem Geology 20:205-221

Cranwell PA (1978) Extractable and bound lipid components in a freshwater sediment. Geochim et Cosmochim Acta 42:1523-1532

Cranwell PA (1981) Diagenesis of free and bound lipids in terrestrial detritus deposited in a lacustrine sediment. Org Geochem 3:79-89

Dinel H, Monreal CM, Schnitzer M (1998) Extractable lipids and organic matter status in two soil catenas as influenced by tillage. Geoderma 86:279-293

Disnar JR, Guillet B, Kéravis D, Di-Giovanni C, Sebag D (2003) Soil organic matter (SOM) characterization by Rock-Eval pyrolysis: scope and limitations. Org Geochem 34:327-343

Disnar JR, Stefanova M, Bourdon S, Laggoun-Défarge F (2005) Sequential fatty acid analysis of a peat core covering the last twomillennia (Tritrivakely lake, Madagascar): diagenesis appraisal and consequences for palaeoenvironmental reconstruction. Org Geochem 36:1391-1404

Dupouey JL, Dambrine E, Laffite JD, Moares C (2002) Irreversible impact of past land use on forest soils and biodiversity. Ecology 83:2978-2984

Eglinton G, Hunneman DH (1968) Gas chromatographic-mass spectrometric studies of long chain hydroxy acids-I: The constituent cutin acids of apple cuticle. Phytochem 7:313-322

Embrapa (1997) Manual de métodos de análise de solo. 2 ed. Empresa Brasileira de Pesquisa Agropecuária, Rio de Janeiro

Espelie KE, Kolattukudy PE (1979) Composition of the aliphatic components of 'suberin' from the bundle sheaths of Zea mays leaves. Plant Science Letters 15:225-230

Espitalié J, Derro G, Marquis F (1985) La pyrolyse Rock-Eval et ses applications. Revue de l'IFP 40:563-579

Feng X, Xu Y, Jaffé R, Schlesinger WH, Simpson M J (2010) Turnover rates of hydrolysable aliphatic lipids in Duke Forest soils determined by compound specific 13C isotopic analysis. Org Geochem 41:573-579

Ficken KJ, Li B, Swain DL, Eglinton G (2000) An n-alkane proxy for the sedimentary input of submerged/floating aquatic macrophytes. Org Geochem 31:745-749

Fisher E, Oldfield F, Wake R, Boyle J, Appleby P, Wolff G (2003) Molecular marker records of land use change. Org Geochem 34:105-119

Foster DR (1992) Land-use history (1730-1990) and vegetation dynamics in central New England, USA. J of Ecol 80:753-772

Franke R, Briesen I, Wojciechowski T, Faust A, Yephremov A, Nawrath C, Schreiber L (2005) Apoplastic polyesters in Arabidopsis surface tissues - a typical suberin and a particular cutin. Phytochem 66:26432658

Glatzel G (1991) The impact of historic land-use and modern forestry on nutrient relations of Central European forest ecosystems. Fertilizer Research 27:1-8

Gleixner G, Czimczik C J, Kramer C, Lühker B, Schmidt MWI (2001) Plant compounds and their turnover and stabilization as soil organic matter. Global Biogeochemical Cycles in the Climate System, pp 201-215

Goñi MA, Hedges JI (1990) The diagenetic behavior of cutin acids in buried conifer needles and sediments from a coastal marine environment. Geochim et Cosmochim Acta 54:3083-3093 
Heim A, Hofmann A, Schmidt M (2010) Forest-derived lignin biomarkers in an Australian oxisol decrease substantially after 90 years of pasture. Org geochem 41:1219-1224

Hermy M (1994) Effects of former land use on plant species diversity and pattern in European deciduous woodlands. In: Boyle TJB, Boyle CEB (eds) Biodiversity, temperate ecosystems, and global change. Springer-Verlag, Berlin, Germany, pp 123-144

Ho ES, Meyers PA (1994) Variability of early diagenesis in lake sediments. Evidence for the sedimentary geolipid record in an isolated tarn. Chem Geol 112: 309-324

Holloway PJ (1982) The chemical constitution of plant cutins. In: Cutler DF, Alvin K, Price CE (eds) The Plant Cuticle. Linnean Society Symposium Series No 10. Academic Press, London, pp 45-85

Huang Y, Lockheart MY, Logan GA, Eglinton G (1996) Isotope and molecular evidence for the diverse origins of carboxylic acids in leaf fossils and sediments from Miocene lake Clarkia deposit Idaho USA. Org Geochem 24:289-299

Institut Géographique National. Aerial pictures of 1946. http://www.ign.fr/. Accessed 10 July 2010

Jacob J, Disnar JR, Boussafir M, Ledru M-P, Albuquerque ALS, Sifeddine A, Turcq B (2005) Pentacyclic triterpene methyl ethers in recent lacustrine sediments (Lagoa do Caçó, Brazil). Org Geochem 36: 449-461

Jacob J, Huang Y, Disnar JR, Sifeddine, A, Boussafir M, Albuquerque ALS, Turcq B (2007) Paleohydrological changes during the last deglaciation in Northern Brazil. Quat Sci Rev 26:1004-1015

Jandl G, Leinweber P, Schulten R, Ekschmitt K (2005) Contribution of primary organic matter to the fatty acid pool in agricultural soils. Soil Biol Biochem 37:1033-1041

Jambu P, Mouçawi J, Fustec E, Amblès A, Jacquesy R (1985) Interrelation entre pH et la nature des composés lipidiques du sol: étude comparée d'une rendzine et d'un sol lessivé glossique. Agrochimica 29:186-198

Jambu P, Bilong P, Amblès A, Ntsikoussalabongui B, Fustec E (1987) Influence d'apports minéraux sur l'évolution des lipides naturels des sols acides. Sci du sol 25:161-172

Järvinen R (2010) Cuticular and suberin polymers of edible plants. Analysis by gas chromatographic-mass spectrometric and solid state spectroscopic methods. Dissertation, Turku University

Kasel S, Bennett L (2007) Land-use history, forest conversion, and soil organic carbon in pine plantations and native forests of south eastern Australia. Geoderma 137:401-413

Koerner W, Dupouey JL, Dambrine E, Benoit M (1997) Influence of past land use on the vegetation and soils of present day forest in the Vosges mountains, France. J Ecol 85:351-358

Kolattukudy PE (1980) Cutin, Suberin and Waxes. The Biochemistry of Plants: IV. Lipids, Structure and Function, Academic Press, New York

Kusch S, Rethemeyer J, Schefuß E, Mollenhauer G (2010) Controls on the age of vascular plant biomarkers in Black Sea sediments. Geochim et Cosmochim Acta 74:7031-7047

Lafargue E, Marquis F, Pillot D (1998) Rock-Eval 6 applications in hydrocarbon exploration, production, and soil contamination studies. Revue de l'IFP 53:421-437

Lecomte J (2009) Les cires végétales : sources et applications. OCL 16:4, 262-266. doi: 10.1684/ocl.2009.0273

Margesin R, Schinner F (2005) Manual of Soil Analysis. Monitoring and Assessing Soils Bioremediation. Springer-Verlag, Berlin Heidelberg, Germany

Lichtfouse E, Elbisser B, Balesdent J, Mariotti A, Bardoux G (1994) Isotope and molecular evidence for direct input of maize leaf wax n-alkanes into crop soil. Org Geochem 22:349-351 
Marseille F, Disnar JR, Guillet B, Noack Y (1999) n-Alkanes and free fatty acids in humus and A1 horizons of soils under beech, spruce and grass in the Massif Central (Mont-Lozère) France. Eur J of Soil Sci 50:433441

Martins CMC, Mesquita SMM, Vaz WLC (1999) Cuticular Waxes of the Holm (Quercus ilex L. subsp. ballota (Desf.) Samp.) and Cork (Q. suber L.) Oaks. Phytochem Anal 10:1-5

Matzke K, Riederer M (1991) A comparative study into the chemical constitution of cutins and suberins from Picea abies (L.) Karst., Quercus robur L. and Fagus sylvatica L. Planta 185:233-245

Meyers PA, Ishiwatari R (1993) Lacustrine organic geochemistry - An overview of indicators of organic matter sources and diagenesis in lake sediments. Org Geochem 20:867-900

Michelin Y (1996) Les jardins de Vulcain : Paysages d'hier, d'aujourd'hui et de demain, dans la chaîne des Puys du Massif central français. Maison des Sciences de 1'Homme, Paris

Moucawi J, Fustec E, Jambu P (1981) Decomposition of lipids in soils: free and esterifed fatty acids, alcohols and ketones. Soil Biol Biochem 13:461-468

Naafs DFW, van Bergen PF, Boogert SJ, de Leeuw JW (2004) Solvent-extractable lipids in an acid andic forest soil; variations with depth and season. Soil Biol Biochem 36:297-308

Verstraten JM (2003) Occurrence and distribution of ester-bound lipids in Dutch coastal dune soils along a pH gradient. Org Geochem 34:719-729

Nierop KGJ, Verstraten JM (2003) Organic matter formation in sandy subsurface horizons of Dutch coastal dunes in relation to soil acidification. Org Geochem 34:499-513

Nierop KGJ, Naafs DFW, van Bergen PF (2005) Origin, occurrence and fate of extractable lipids in Dutch coastal dune soils along a pH gradient. Org Geochem 36:555-566

Otto A, Simpson MJ (2006) Sources and composition of hydrolysable aliphatic lipids and phenols in soils from western Canada. Org Geochem 37:385-407

Pollard M, Beisson F, Li Y, Ohlrogge JB (2008) Building lipid barriers: biosynthesis of cutin and suberin. Trends Plant Sci. 13:236-246

Powers JS, Veldkamp E (2005) Regional variation in soil carbon and $\delta^{13} \mathrm{C}$ in forests and pastures of northeastern Costa Rica. Biogeochem 72:315-336

Prartono T, Wolff GA (1998) Organic geochemistry of lacustrine sediments: evidence for the changing trophic status of the lake, Rostherne Mere, UK. Org Geochem 28:729-747

Priigelt B, Lognay G (1996) Composition of the Cuticular Waxes of Picea abies and P. sitchensis. Phytochem Anal 7:29-36

Quenea K, Largeau C, Derenne S, Spaccini R, Bardoux G, Mariotti A (2006) Molecular and isotopic study of lipids in particle size fractions of a sandy cultivated soil (Cestas cultivation sequence, southwest France): Sources, degradation, and comparison with Cestas forest soil. Org Geochem 37:20-44

Rieley G, Collier RJ, Jones DM, Eglinton G (1991) The biogeochemistry of Ellesmere Lake, UK-I source correlation of leaf wax inputs to the sedimentary lipid record. Org Geochem 17:901-912

Ruess L, Chamberlain PM (2010) The fat that matters: Soil food web analysis using fatty acids and their carbon stable isotope signature. Soil Biol Biochem 42:1898-1910

Shepherd T, Griffiths DW (2006) The effects of stress on plant cuticular waxes. New Phytologist 171: 469-499 
Six J, Conant RT, Paustian PEA (2002) Stabilization mechanisms of soil organic matter: Implications for Csaturation of soils. Plant Soil 241:155-176

Stefanova M, Disnar JR (2000) Composition and early diagenesis of fatty acids in lacustrine sediments, lake Aydat (France). Org Geochem 31:41-55

Tissot BP, Welte DH (1984) Petroleum Formation and Occurrence, $2^{\text {nd }}$ ed. Springer-Verlag, Berlin, $700 \mathrm{p}$

Torn MS, Trumbore SE, Chadwick OA, Vitousek PM, Hendricks DM (1997) Mineral control of soil organic carbon storage and turnover. Nature 389:170-173

Wakeham SG (1999) Monocarboxylic, dicarboxylic and hydroxy acids released by sequential treatments of suspended particles and sediments of the Black Sea. Org Geochem 30:1059-1074

Wiesenberg GLB, Schwark L (2006) Carboxylic acid distribution patterns of temperate C3 and C4 crops. Org Geochem 37:1973-1982

Wiesenberg GLB, Schwarzbauer J, Schmidt MWI, Schwark L (2004) Source and turnover of organic matter in agricultural soils derived from n-alkane/n-carboxylic acid compositions and $\mathrm{C}$-isotope signatures. Org Geochem 35:1371-1393

Wiesenberg GLB, Schwarzbauer J, Schmidt MWI, Schwark L (2008) Plant and soil lipid modification under elevated atmospheric $\mathrm{CO}_{2}$ conditions: II. Stable carbon isotopic values $\left(\delta^{13} \mathrm{C}\right)$ and turnover. Org Geochem 39:103-117

Wiesenberg GLB, Dorodnikov M, Kuzyakov Y (2010) Source determination of lipids in bulk soil and soil density fractions after four years of wheat cropping. Geoderma 156:267-277

Zelles L (1997) Phospholipid fatty acid profiles in selected members of soil microbial communities. Chemosphere 35, 275-294 
Table 1 Edaphic and topographic characteristics of soil samples of Lake Aydat catchment with Rock Eval pyrolysis data and FA concentrations. IH values are expressed in mg HC.g ${ }^{-1}$ TOC and OI in mg $\mathrm{CO}_{2} \cdot \mathrm{g}^{-1}$ TOC

\begin{tabular}{|c|c|c|c|c|c|c|c|c|c|c|c|c|c|}
\hline \multirow[t]{2}{*}{ Site } & \multirow{2}{*}{$\begin{array}{l}\text { Vegetation } \\
\text { (humus type) }\end{array}$} & \multirow{2}{*}{$\begin{array}{l}\text { Geological } \\
\text { substratum }\end{array}$} & \multicolumn{3}{|c|}{ Granulometry } & \multirow{2}{*}{$\begin{array}{l}\text { Slope } \\
\left(^{\circ}\right)\end{array}$} & \multirow{2}{*}{$\begin{array}{l}\text { Elevation } \\
\qquad(\mathrm{m})\end{array}$} & \multirow{2}{*}{$\mathrm{pH}_{\mathrm{CaCl} 2}$} & \multirow{2}{*}{$\begin{array}{l}\text { TOC } \\
(\%)\end{array}$} & \multirow[t]{2}{*}{ HI } & \multirow[t]{2}{*}{ OI } & \multirow{2}{*}{$\begin{array}{l}\text { FA conc. } \\
\left(\mu \mathrm{g} . \mathrm{g} \mathrm{soil}^{-1}\right)\end{array}$} & \multirow{2}{*}{$\begin{array}{l}\text { FA conc. } \\
\left(\mu \mathrm{g} . \mathrm{g} \mathrm{TOC}^{-1}\right)\end{array}$} \\
\hline & & & $\begin{array}{c}\text { Sand } \\
(\%)\end{array}$ & $\begin{array}{l}\text { Silt } \\
(\%)\end{array}$ & $\begin{array}{l}\text { Clay } \\
(\%)\end{array}$ & & & & & & & & \\
\hline S08 & grassland & Basaltic & & & & 3.4 & 1096 & 5.27 & 12.5 & 310 & 178 & 186 & 1491 \\
\hline S09 & grassland & Basaltic & & & & 9 & 1081 & 5.48 & 14.3 & 322 & 230 & 150 & 1048 \\
\hline S10 & grassland (+ shrubs) & Basaltic & & & & 13.2 & 1061 & 4.96 & 13.7 & 257 & 188 & 113 & 823 \\
\hline S11 & grassland (+ shrubs) & Basaltic & & & & 13.4 & 1047 & 4.66 & 11.2 & 267 & 197 & 145 & 1303 \\
\hline S12 & grassland & Basaltic & & & & 9.3 & 1034 & 5.78 & 25.7 & 322 & 209 & 317 & 1230 \\
\hline S13 & grassland & Basaltic & & & & 2.4 & 1023 & 5.26 & 6.6 & 327 & 176 & 120 & 1813 \\
\hline S14 & grassland & Basaltic & & & & 9.8 & 1032 & 5.53 & 5.2 & 271 & 209 & 63 & 1210 \\
\hline S15 & grassland & Basaltic & & & & 10.4 & 1045 & 5.24 & 6.2 & 262 & 255 & 312 & 5029 \\
\hline S17 & grassland & Basaltic & & & & 3.4 & 1075 & 5.52 & 7.1 & 286 & 182 & 485 & 6794 \\
\hline S02 & grassland & Quat. Alluv. & & & & 0.5 & 956 & 5.54 & 10.6 & 285 & 206 & 322 & 3025 \\
\hline S03 & grassland & Basaltic & & & & 2.4 & 957 & 5.27 & 6.6 & 218 & 207 & 236 & 3583 \\
\hline S20 & grassland & Basaltic & 22 & 75 & 4 & 5.7 & 975 & 5.76 & 9.4 & 271 & 192 & 146 & 1561 \\
\hline S05 & intermediate & Doreit & & & & 2.4 & 1268 & 4.52 & 16.2 & 352 & 167 & 843 & 5216 \\
\hline S28 & intermediate & Basaltic & & & & 8.7 & 1055 & 5.32 & 7.5 & 236 & 208 & 501 & 6636 \\
\hline S33 & intermediate & Basaltic & & & & 4 & 1038 & 5.01 & 29.7 & 378 & 176 & 486 & 1639 \\
\hline S34 & intermediate & Basaltic & 49 & 47 & 4 & 11 & 980 & 5.2 & 10.8 & 232 & 211 & 370 & 3418 \\
\hline S26 & forest & Basaltic & & & & 16.6 & 1075 & 4.2 & 38.2 & 364 & 248 & 317 & 833 \\
\hline S36 & forest & Basaltic & 58 & 40 & 2 & 14.9 & 995 & 5.45 & 8 & 220 & 378 & 1877 & 23349 \\
\hline
\end{tabular}

Legend: Quat. Alluv. = Quaternary Alluvion, $\mathrm{HI}=$ hydrogen index, OI = oxygen index. 


\section{FIGURE CAPTIONS}

Fig. 1 Location of lake Aydat catchment area (French Massif Central). Soil sampling sites are represented by white circles. The profile shows the topography of a transect from S08 to S17 sites.

Fig. 2 Partial GC-MS chromatograms (TIC) of the methylated and silylated acid fractions of soil lipid extracts from Lake Aydat catchment. S14: grassland soil sample; S26: forest soil sample.

Fig. 3 Histograms showing the distributions of nFAs in lipid extracts of soil collected in grassland (S09 and S14), intermediate (S33 and S34) and forest regions (S26 and S36) of the Lake Aydat catchment.

Fig. 4 Histograms showing the distributions of $\omega$ HOFAs in lipid extracts of soil collected in grassland (S09 and S14), intermediate (S33 and S34) and forest regions (S26 and S36) of the Lake Aydat catchment soils.

Fig. 5 Histograms showing the distributions of $\alpha$ HOFAs in lipid extracts of soil collected in grassland (S09 and S14), intermediate (S33 and S34) and forest regions (S26 and S36) of the Lake Aydat catchment.

Fig. 6 Histograms showing the distributions of diFAs in lipid extracts of soil collected in grassland (S09 and S14), intermediate (S33 and S34) and forest regions (S26 and S36) of the Lake Aydat catchment.

Fig 7 Summary of the most informative parameters yielded by the analysis of free lipids extracted from soils developed in the catchment of Lake Aydat. (a) Distribution of nFAs, $\omega$ HOFAs, $\alpha$ HOFAs and diFAs homologues according to the type of soil. Darker greys indicate the predominance of distinct homologues (b) Distribution of selected parameters $\left[\left(\mathrm{C}_{26: 0}+\mathrm{C}_{28: 0}\right) / \Sigma \mathrm{C}_{\text {even }} n F A s\right.$, (c) $\mathrm{C}_{22} / \mathrm{C}_{24}$ diFAs, and (d) $\mathrm{C}_{20} / \mathrm{C}_{20+} \omega$-HOFAs $]$ depending on soil type.

Fig. 8 Concentrations in deoxycholic acid in grassland, intermediate and forest soil samples from Lake Aydat catchment. 


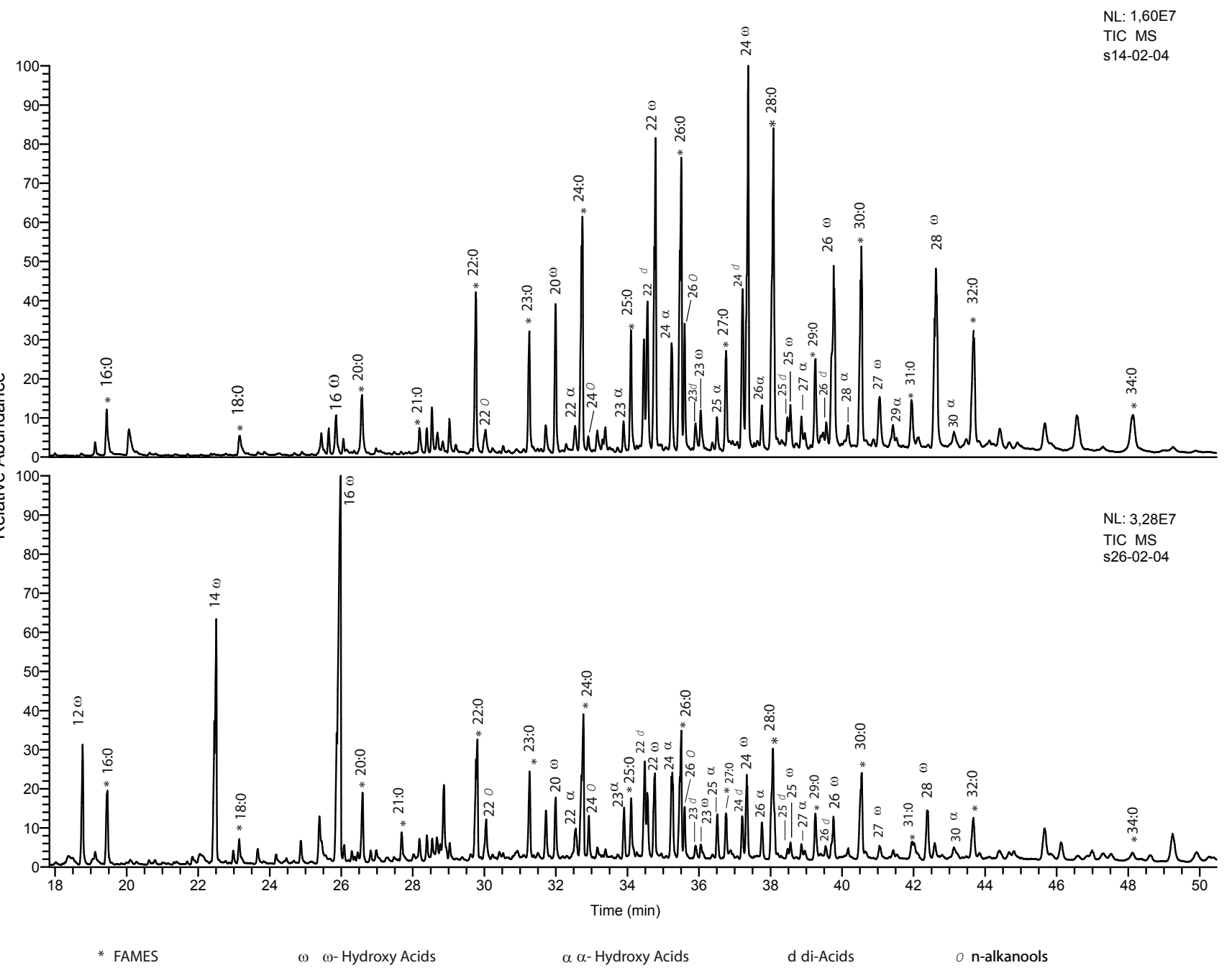




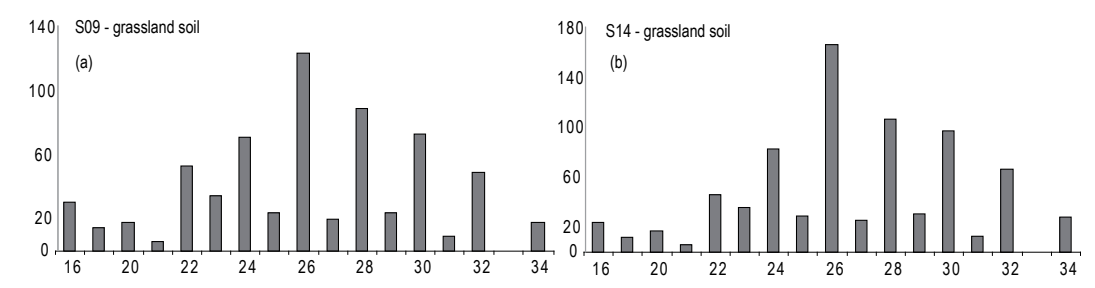

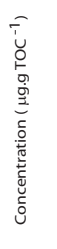
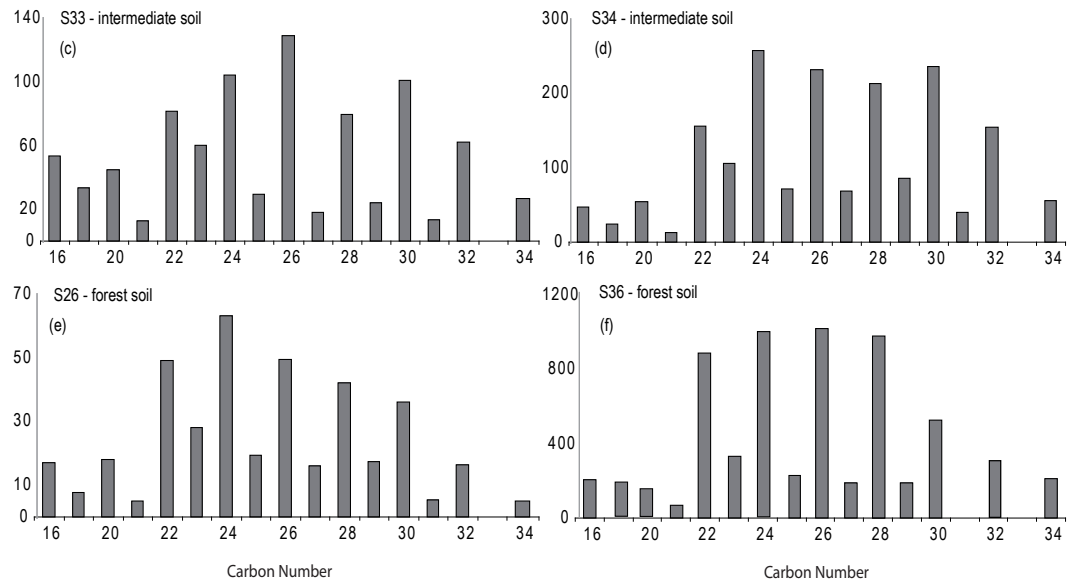


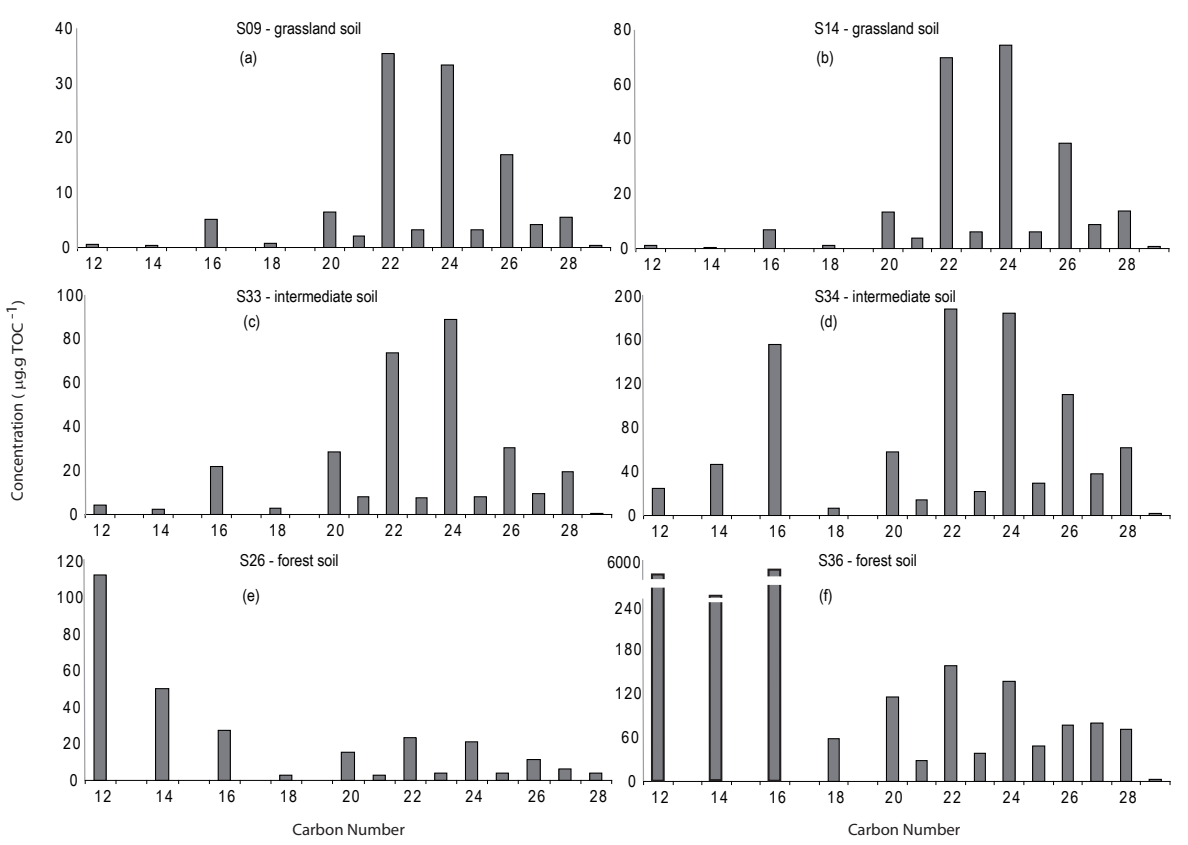




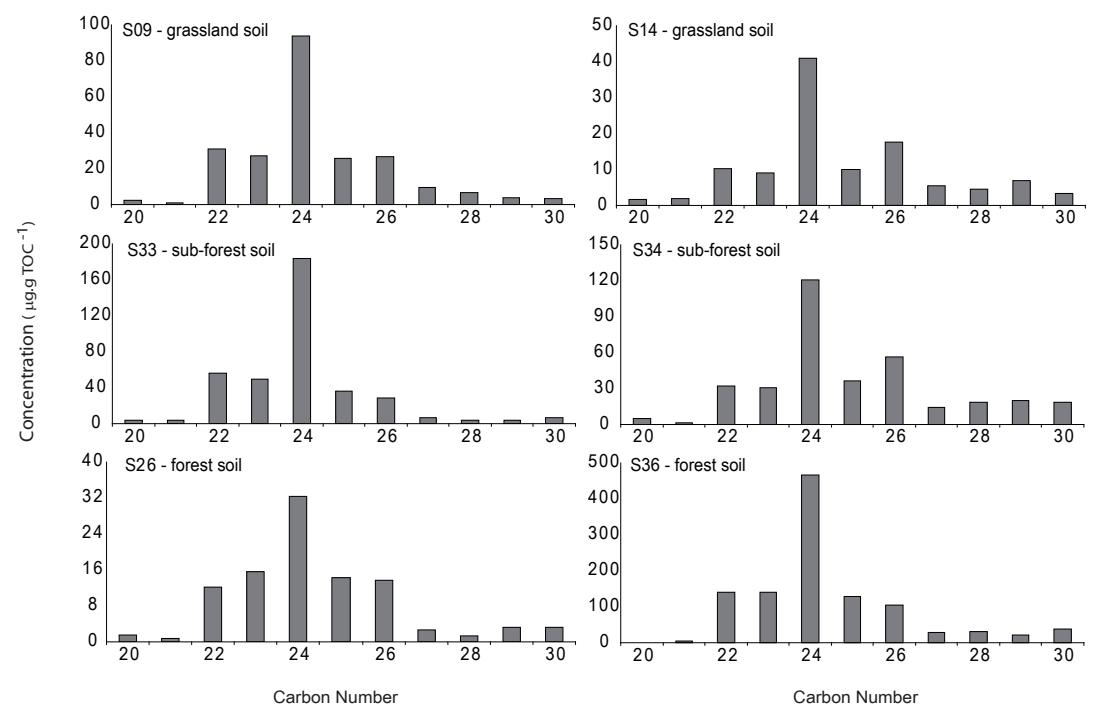



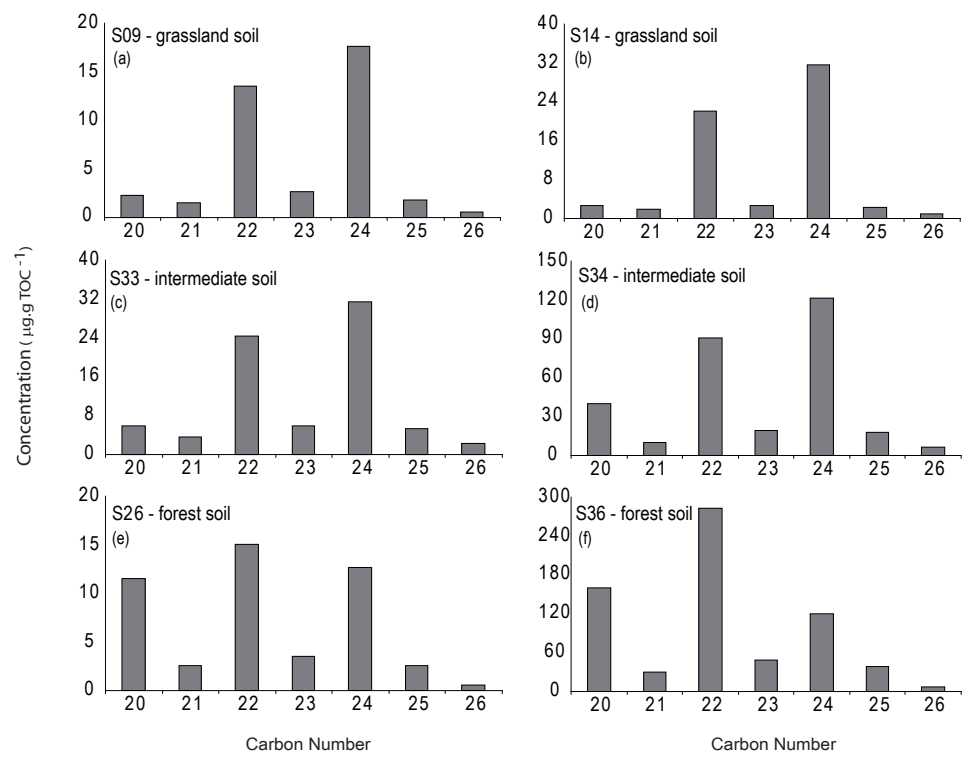

${ }^{150}$ S34 - intermediate soil
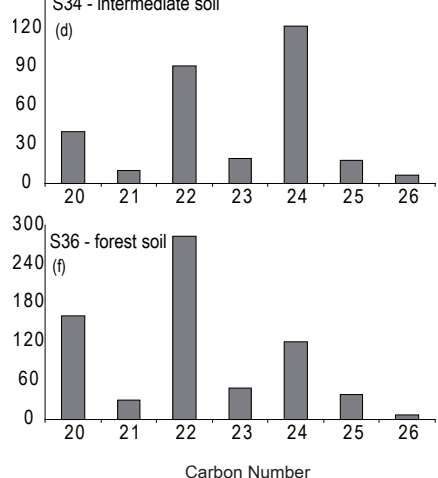


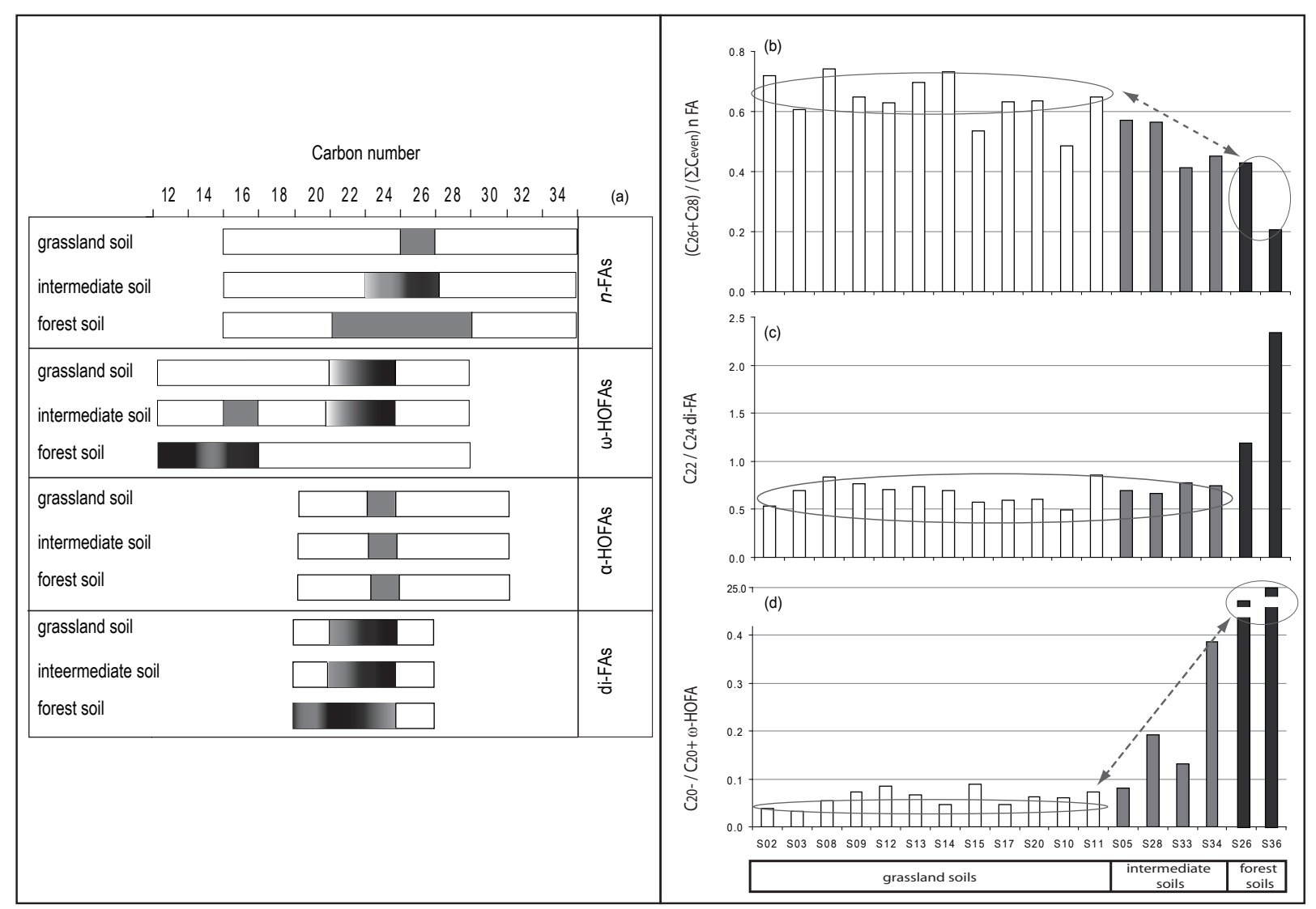




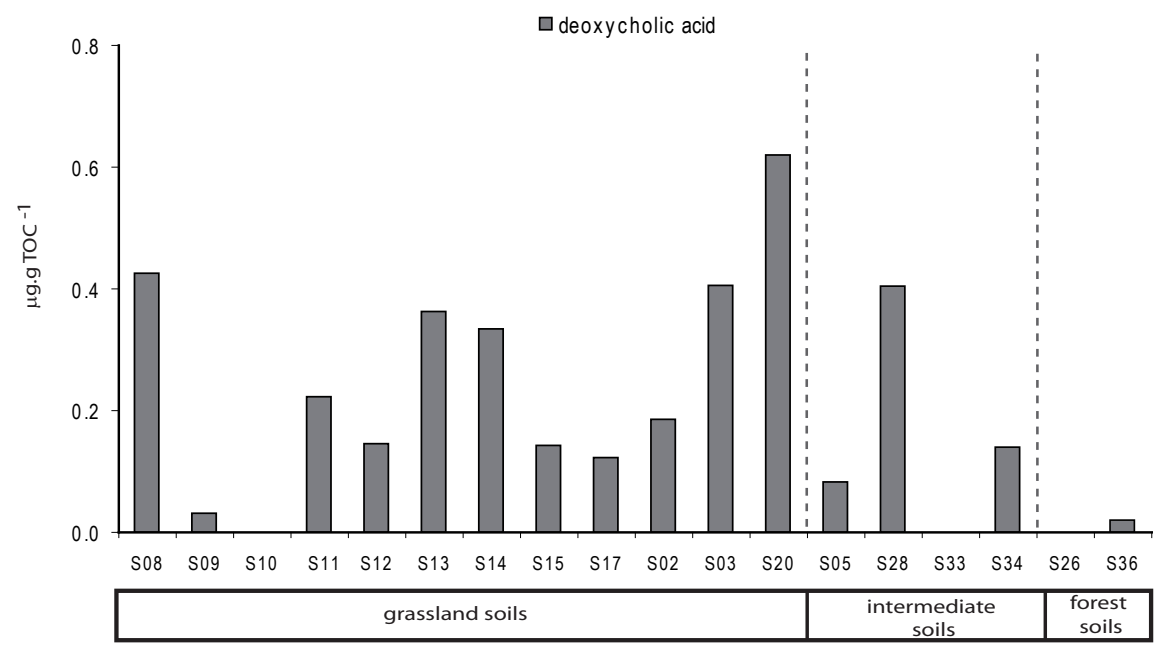

